\title{
FORUM
}

Submitted 09.30.2016. Approved 03.14.2017

Evaluated by double-blind review process. Scientific Editors: Marlei Pozzebon, Eduardo Henrique Diniz, Nathalie Mitev, François-Xavier de Vaujany, Miguel Pina e Cunha, and Bernard Leca

DOI: http://dx.doi.org/10.1590/So034-759020170604

\section{COLLABORATIVE AGENCY IN EDUCATIONAL MANAGEMENT: A JOINT OBJECT FOR SCHOOL AND COMMUNITY TRANSFORMATION}

\author{
Agência colaborativa na gestão educacional: Um objeto conjunto para a \\ transformação da escola e da comunidade \\ Agencia colaborativa en gestión educativa: Objeto conjunto para transformación \\ escolar y comunitaria
}

\begin{abstract}
This research paper discusses activities developed in a school located in a favela in the city of São Paulo, Brazil, and its surrounding community to deal with the issue of flooding. First, I present a review of the literature on educational management suggesting an expansive learning perspective, then I introduce the notion of collaborative agency as theoretical background. Methodologically, this study focuses on critical collaborative research and formative intervention, which implies different subjects taking part and negotiating decisions to be made during the research beyond school settings. The analysis is based on categories of description and argumentation, which contribute to the scrutiny of different voices and activities in the respective school and community. Thus, I discuss how collaborative agency contributes to the transformation of the given context: first, how the community becomes involved in the activities of the school, and second, how the school is involved in the activities of the community to overcome the problem of flooding. KEYWORDS | Collaborative agency, educational management, school-community transformation, critical collaborative research, formative interventions.
\end{abstract}

\section{RESUMO}

Este trabalho de pesquisa discute as atividades desenvolvidas em uma escola de uma favela na cidade de São Paulo, Brasil, e na sua comunidade para lidar com o problema das inundações. Primeiro, apresento uma revisão da literatura sobre a gestão educacional que sugere uma perspectiva de aprendizagem expansiva, logo, sendo o meu contexto teórico, passo a debater a noção de agência colaborativa. Do ponto de vista metodológico, este estudo centra-se em uma pesquisa colaborativa crítica e em uma intervenção formativa, o que implica na participação de diferentes sujeitos e que decisões de negociação sejam tomadas durante a pesquisa, para além dos muros da escola. A análise baseia-se nas categorias de descrição e argumentação, que contribuem para o escrutínio de vozes e atividades diferentes, na respectiva escola e comunidade. Assim, abordo como a agência colaborativa contribui para a transformação de um determinado contexto: primeiro, como a comunidade se torna envolvida nas atividades escolares e, segundo, como a escola está envolvida nas atividades da comunidade para superar o problema das inundações.

PALAVRAS-CHAVE / Agência colaborativa, gestão educacional, transformação escola-comunidade, pesquisa colaborativa crítica, intervenções formativas.

\section{RESUMEN}

El presente artículo trata actividades realizadas en una escuela localizada en una favela en la ciudad de São Paulo, Brasil, y su comunidad vecina para tratar el tema de inundaciones. En primer lugar, presento una reseña de la literatura sobre gestión educativa sugiriendo una perspectiva de aprendizaje expansiva, luego, como mi fondo teórico, se trata la noción de agencia colaborativa. Metodológicamente, este estudio se concentra en estudio colaborativo crítico e intervención formativa, que implica diferentes individuos participando y negociando decisiones que se tomarán durante el estudio más allá de los entornos escolares. El análisis se basa en categorías de descripción y argumentación, lo que contribuye al escrutinio de diferentes voces y actividades en las respectivas escuela y comunidad. Por lo tanto, trato cómo la agencia colaborativa contribuye a la transformación del contexto dado: en primer lugar, cómo la comunidad se involucra en las actividades de la escuela, y en segundo, cómo la escuela está involucrada en las actividades de la comunidad para superar el problema de las inundaciones.

PALABRAS CLAVE I Agencia colaborativa, gestión educativa, transformaciones escolares-comunitarias, estudio colaborativo crítico, intervención formativa.

\author{
monica.lemos@helsinki.fi \\ PhD candidate at the Helsingin \\ - Helsinki, Finland
}




\section{INTRODUCTION}

Most public schools in Brazil's metropolitan areas are in outskirt communities, which also means that schools are surrounded by violence and marginalization, as in the city of São Paulo, where this research was conducted. According to INPE, the National Institute for Spatial Research, 2.7 million people live in the favelas-heavily populated urban areas with low standards of housing, according to United Nation standards (UN-Habitat, 2003)-or other type of precarious marginalized housing. Consequently, it is very common for students, teachers, and educational managers who have the right to go to school or to work to be threatened. Since criminality and poverty in their living and working contexts are so great, they need to develop tools to provide education inside and outside schools and mitigate less marginalization.

With this context, the background of this study comprises a chain of activities to improve educational systems. Such educational systems face the dilemma of implementing policies focused on tests and assessments results and working within the social realities of marginalization, not only of students but also of educational professionals (Liberali, 2012a, 2012b). According to Liberali, Borelli, and Lima (2015), as a result of evaluation systems, educational managers become more concerned about grades, reports, and aims instead of teaching, learning, and the transformation of communities.

Thus, this study analyzes how improving educational management activities can lead to the transformation of a school and its surroundings from a Cultural Historical Activity Theory perspective. More specifically, the study analyzes an educational management organization that struggled to overcome a flooding problem. In this specific case, a river flows between community and school, and when it floods, it prevents most of the children from going to school.

The whole process is based on the theoretical support of Cultural Historical Activity Theory (Engeström, 2009a, 2015; Leontiev, 1978), henceforth "CHAT," focusing on collaborative agency as way to potentiate individuals in a collective movement to overcome the issues of day-to-day life in a large city. In this sense, sociomateriality is embedded in the discussion throughout the paper, since educational management in the CHAT perspective involves subjects collectively raising their needs and developing tools to reach their object, bearing in mind rules, the community, and the division of labor (Engeström \& Ahonen, 2005).

In addition, this paper discusses a management model that points to a cultural-historical and social movement at school in opposition to a view that points to management as an administration model, which is closer to the notion of democratic management (Brasil, 1988, 1996). Therefore, the case of a specific school is analyzed to understand the management movement from inside to outside school.

Therefore, I discuss how a collaborative agentive movement can contribute to calling authorities' attention to problems of the community and school, with the flood taking the school to the community and the community to the school. Collaborative agency has the potential to contribute to educational management expansion through activities organized beyond the school walls.

\section{EDUCATIONAL MANAGEMENT REVIEW: FROM ENCAPSULATION TO EXPANSION}

For a long period, educational management has been understood as a tool or a technique to organize school work (Souza, 2006). Kumpulainen and others (2010) also point out that educational management is associated with school administration. In addition, according to Bush (2011, p. 14) “educational management as a field of study and practice was derived from management principles first applied to industry and commerce, mainly in the United States. It was very much influenced by the work of Taylor and the scientific management perspective in which individuals' actions were to be adjusted into new, efficient machines (Hoy \& Miskel, 2013, p. 13). Also from a North American perspective, Hoy and Miskel (2013) state that the systematic study of educational administration is as new as the modern school. The authors define administration as the art and the science of applying knowledge to administrative organizational problems (Hoy \& Miskel, 2013, p.78).

In Brazil, research on educational management started in the 1920 s with the pioneers of education (Lourenço Filho, 1968; Teixeira, 1961), who also took classical administration as a principle and scientific administration as their background.

More recently, quality in the student learning process has been adopted as the basis of educational management in Brazil (Lück, 2009), and it is measured by a variety of national, state, and local assessments. Such focus on assessment diverts the focus from organizing management for teaching and learning or for community transformation, making educational managers more concerned about aims and results rather than knowledge and development (Lemos \& Engeström, submitted manuscript) On the other hand, Sahlberg (2011) states that educational 
quality measurable by tests related to ranking and awards does not contribute to real school improvement. Based on Engeström (1991), this kind of improvement would entail encapsulation of educational management.

Sahlberg (2011) claims that decisions made together with school participants, including students and parents, in the discussion of institutional goals, combined with students' results on tests, external and internal evaluations, parents' comments, and school self-evaluation, provide better school development and consequent improvements in the results. More than that, a closer relationship between the school, community members, and other stakeholders, rather than reducing would promote the expansion of educational management.

Suggesting that educational management could be materialized in an expansive learning perspective would demand educational teams "constructing and implementing a radically new, wider and more complex object and concept of their activity" (Engeström \& Sannino, 2010, p. 2), not in a vertical hierarchized structure but in a horizontal dimension (Engeström, 2003).

Therefore, expansive learning encompasses learning something that is not yet there (Engeström, 2015; Rantavuori, Engeström, \& Lipponen, 2016). Thus, “transformation of an activity is never an isolated process; it also means redefinition of its boundaries and thus renegotiation of its external relationships" (Engeström, 2009b, p. 16). In this line, Freire (2014) reminds us of the importance of respecting the knowledge socially produced in communities outside the classroom, school offices, or cabinets.

In the sociomaterial perspective, CHAT is a theoretical conception that reclaims and re-thinks social material practice (Fenwick, 2010; Fenwick, Edwards, \& Sawchuk, 2011) and expansive learning is mainly an object-oriented and driven activity (Engeström, 2009a; Leontiev, 1978; Rantavuori et al., 2016) in which the object is strictly connected to the needs of subjects loaded with meaning (Engeström, Engeström, \& Suntio, 2002), motivating power and hope (Freire, 1970). Objects define the horizon of possible actions; they embody the motive and the meaning of the collective activity (Engeström, 1994; Engeström et al., 2002)

In this study, the object of activity is crucial to develop the expansion of educational management beyond school walls. This need, triggered by the motive of activity which directs the object, is essential to the projection and development of activities to overcome different types of crisis (Lemos, 2015).

In complex activity systems and complex organizations, such as expansive educational management, practitioners need to construct a connection between the goals of their ongoing actions and the more durable object/motive of the collective activity system. After all, objects seem to have lives of their own (Engeström, 1995) and "yet, the object is both resistant raw material and the future-oriented purpose of an activity" (Rantavuori et al., 2016, p. 4). In expansive educational management, the object to be transformed and expanded carries motive and motivation, which, according to Rantavuori et al. (2016), are not primarily located in individual subjects, which thus demands collaborative effort to be achieved.

\section{COLLABORATIVE AGENCY}

Here I discuss the notion of collaborative agency proposed initially by Miettinen $(2010,2013)$, which is the foundation of this article. Miettinen describes collaborative agency as a central phenomenon for the promotion of a creative encounter in which participants engage towards a joint object. The reasons for the encounters are mostly related to the need to expand expertise by finding a new product, raw material, or market or solving a specific problem. In this perspective, the idea of togetherness developed by van Oers and Hännikäinen (2001) is useful for viewing collaborative agency as more than a conglomerate of people working together. In this work, togetherness is related to the formation of the joint object, which is by its nature a hypothesis, an imagined and open "horizon of possibility" that will gradually be materialized (Miettinen, 2010).

The work analyzed in this study is strongly connected to the tradition of intervention as a way of transforming situations of injustice. According to Engeström, Sannino, and Virkkunen (2014), transformative agency develops the participants' joint activity by explicating and envisioning new possibilities for collective efforts for change rather than individual ones. In this case, it is not possible to think about collaborative agency without considering the transformative bias implicated on it.

Therefore, I understand collaborative agency as a process in which participants become agents of an activity by collaboratively constructing and envisioning new possibilities for achieving a joint object in order to transform not only the focus of research or a work setting but also people's lives. In that sense, collaborative agency implies different participants' voices, actions, and reflections in and over activities to transform their realities. In the specific case of this article, collaborative agency is related to the tools a school develops in educational management to deal with issues beyond the school walls.

The notion of collaborative agency relates to sociomateriality for four reasons. First, according to Fenwick (2010), 
sociomateriality involves the material practices in working life that are essential to understanding human activity and meaning making. Second, sociomateriality can help reveal the dynamics shaping everyday life, including working and learning. Such dynamics involve, in the third place, the materiality embedded in the development of structures and tools, including the materiality of human beings (Engeström \& Ahönen, 2005). Finally, Engeström and Ahönen (2005) suggest sharing, which permeates the notion of collaborative agency, as a form of sociomateriality.

To be precise, this study contributes to the discussion on sociomateriality by offering the possibility of thinking about agency in a collaborative and transformative ways through the development of new tools in educational management.

\section{Research context}

This study is part of the Management in Creative Chains Project (Liberali, 2012a), whose main objective is to enhance educational management through the development of professional staff, focusing on their studying, training, and monitoring activities in the educational system (Liberali, 2012b).

The educational system in this research involves educational managers whose positions and roles vary in the hierarchical level. At the Secretariat level, there are the Secretary of Education, directors of elementary and high schools, and pedagogical teams, while in the Regional Boards of Education are pedagogical directors, supervisors, and teacher educators. Finally, at the school level are principals, principal assistants, pedagogical coordinators, pedagogical coordinator assistants in some schools, and teachers.

The Management in Creative Chains Project took place from 2011 to 2015 and was organized by formative meetings in the Secretariat of Education and two Regional Boards of Education. The focal study in this research encompasses an intravention, as discussed by Sannino, Engeström, \& Lemos (2016), conducted by a school and its community members during and after the project. While in the formative intervention there was a strong presence of the researchers in developing tools with the educational managers to be further reformulated and applied at schools, in the intravention the researcher acted more as an ethnographer to capture the use of the tools and its consequences due to the formative intervention.

\section{The school context}

The school, named ST, in which data were collected is in the South Zone of the city of São Paulo, between a favela, outskirt houses, and condominiums. There is a river that runs between the school and the community into which people throw garbage due to the lack of garbage collection services. There are 2,252,079 inhabitants living in the South Zone, most of them in the favelas (INPE, 2010). As houses in the favelas are built (mostly) on illegally land, they are the houses most affected by floods during the Brazilian summertime, from January to March, the beginning of the school year.

This specific community is directly affected by the flood because, first, as there is no garbage collection, the garbage is thrown down the hill towards the river. Second, there is no sewage treatment in the community, so people's dejects are also deposited in the stream. When it rains, the stream floods and the sewage overflows, carrying water and dirt into people's houses; thus, many students' families have their belongings and even their houses damaged by or lost to the flooding. There is also a high level of disease in the community from the contaminated flood waters.

\section{METHODS AND DATA}

In this study, I analyze one case in which a school organized with the community to solve the issue of floods. The analysis is based on categories of description and argumentation (Liberali, 2013) from a critical collaborative research perspective (Magalhães, 2016), which contributes to the scrutiny of different voices and activities in the respective school and community. The voice interconnection (Liberali, 2013) as well as responsibility and responsiveness (Bakhtin, 1952; Cunha, van Kruistum \&, van Oers, 2016; Fuga, 2009) are identified by the different use of pronouns throughout the discourse. Such interconnection enables the identification of how participants position themselves and others in the discourse, understood in this study as manifestations of collaborative agency.

Therefore, I report the whole process of activity planning and organization in order to show how school and community members joined to address the flooding problem. The report is based upon one meeting in the Regional Board of Education; two meetings with community members and school members; two interviews with the pedagogical coordinator; one interview with teachers; the school pedagogical project; the school management plan; teachers' yearly planning; and field notes.

Data are organized along a chain of activities focusing on a specific school and its relations with the wider educational system and the community. 


\section{RESULTS}

\section{On the way to school}

Although I had been in contact with the school's management work since the beginning of 2012, the first time I visited the school was in December 2013. I also had the opportunity to participate in certain school activities, such as the annual cultural week, when I could watch several students' presentations on various topics, including such community issues as the flooding, and school council meetings, pedagogical meetings, and community meeting. Exceptionally, I was invited to take part in a ceremony in which the school competed for the city council prize on human rights.

I was very interested in visiting the community so as to get to know more about the people who live in the favela and, if possible, the constraints students find on the way to school, so I decided to go uphill (Subir o morro, the expression used in Portuguese to say that someone is entering a favela). Since it was the last week of school and the pedagogical coordinator was very busy, I decided to go uphill on my own. However, for security reasons I was not allowed to do so. Although I was born in São Paulo and I am familiar with favela contexts, it could be dangerous to go uphill alone since people did not know me. Therefore, one of the pedagogical coordinators, from now on called PCS - Pedagogical Coordinator S - went with me. Besides, as it was also not possible to take camera or microphones, data were collected by a smartphone.

On the way to school there is a long alley that crosses the hill from the bottom to the top and eleven shorter ones. Officially, there is only one main street in the community, and when students need to register for the school year they refer to the main street, not to the alley where they live. As there is no maintenance in the alleys, many people complain about accidents. Moreover, there is no lighting at night, when students return from the school night shift and some workers return home, leading to assaults, drug dealing, and use, and rape, as described in the School Pedagogical Project of 2012.

On "the way to school," we could see different people coming up and down to shop. The school is located between two others, a private school and another public school for early childhood education. One thing worth noting was a man fixing a sewage box for a neighbor, who warned him that rain was coming and all his work might be wasted.

In fact, there are two different ways to go to school. We took the safest way, but the longest for many students, through the alley, while most students literally go downhill and cross a wooden bridge built by the community over the river to the school. Figure 1 depicts the view of part of the community, uphill and the wooden bridge students and dwellers need to cross. Our visit ended on the top of the hill, and upon arriving there we noticed that someone had built a wall so that people would not throw garbage downhill, though this did not help much. During the visit, a bricklayer came and threw buckets of garbage downhill towards the river. Also interesting was a short conversation between PCS and one of her students, who was a boy around nine years old going uphill with someone I naïvely thought might be an older brother, but in fact he was someone trying to lure the boy into using drugs. Later, PCS explained that the boy had stolen school equipment in order to pay his drug debts.

\section{Figure 1. View of the school neighborhood from the school gate. The river runs under the bridge just beside the school}

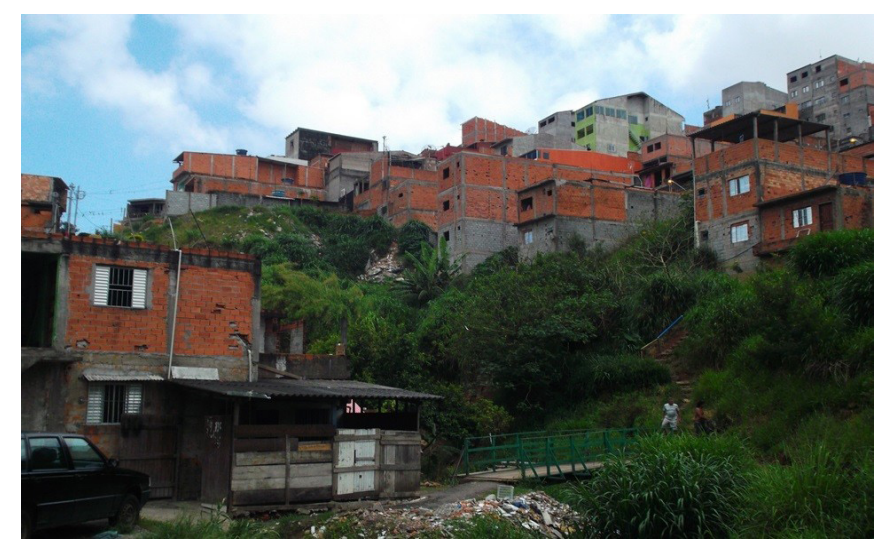

Note: Photo taken by the author

As a foreigner in my own city, I could see things that drew my attention besides the downsides of living in a favela with such problems. There were people chatting and laughing on the streets and boys flying kites. It was also possible to listen to different types of music, from Brazilian folk music to bolero, and, since it was lunchtime, it was possible to smell delicious food being prepared. Finally, although the houses are built in small spaces, and in many instances there a couple of houses are conglomerated, people still find space for gardening, which makes the favela more colorful.

The organization of educational management with the community is essential to overcome the challenges of that context. Therefore, sociomateriality is embedded in the community not only in the way community members live with the specifics of the community, as illustrated by Figure 1, but also by the way community members create tools to deal with the surrounding issues. 


\section{The pedagogical coordinator's participation}

To begin with, PCS took part in the monthly formative meetings during 2011 and 2012 organized for all pedagogical coordinators by the Regional Board of Education. The main objective of the meetings was to develop tools with and for Pedagogical Coordinators so they could improve the educational management at their schools. Pedagogical coordinators were invited to produce a concept of educational management that would be more adequate for the Regional Board of Education (Lemos, 2014; Lemos \& Engeström, submitted manuscript).

Therefore, the concept at the Regional Board of Education should meet the demands of the coordinators in line with the features of different schools in the district. The same would happen at school: they should produce a concept that contemplated school demands, keeping features of the Regional Boards of Education. Excerpt 1 relates the moment when PCS stated what, in her opinion, educational management is for.

\section{Excerpt 1:}

338. PCS. (a) There is something you said that I couldn't get off my mind since our first meeting. Our school has always worked with themes, and there was a polluted stream next to our school. And I felt, and the whole school group felt hypocritical, right? Talking about coexistence (...) living with something that we spend all the time with. (b) To me if teaching-learning does not make my life better, or as a person, as a human being or as pedagogical coordinator, it has no meaning to me. I think it is necessary to have a change for better. We used to make tours around the community every year to get to know about the problems in the community, the history of the community. (c) What for? Then I had an idea... I found the way. Damn, I want to dream of a better school! And when we talk about transforming society, it is not to go there and clean the stream or pick up the trash. I keep thinking, "I deserve it, my students deserve it, and you deserve a better school to have a better quality of life!" (d) So, at the moment that the school wants to transform reality it transforms the mindsets of people who accept anything. So, that's what we try to do there!

From a CHAT perspective, there is no activity without a need (Leontiev, 1978). In Excerpt 1(a), PCS externalizes the need or the problematic situation in her school context: the polluted stream that often floods. PCS defines her view of what educational management is for in part (b), pointing out the historicity of the organization of school activities, as suggested by Engeström (2015). Part (c) describes the moment when PCS envisions possibilities for the future (Engeström, 2009a) by transforming society and engaging students, pedagogical coordinators, and herself in the discourse. Finally, in part (d), the school object, although not yet feasible, is contemplated.

Those formative meetings can be understood as creative encounters, as proposed by Miettinen (2010), given the possibility of starting to envision the joint object of the school, in this case, the transformation of the flood issue. This first movement triggered the pedagogical coordinator's awareness of the situation the school faced and the need for the school and community members to act together to define their joint object, which occurs in part (d).

The same type of formative meeting happened in different schools, and after discussing their definition of what management is for at school ST, they came up with this: "to promote necessary conditions for the good development of all subjects involved in teaching-learning processes and for the transformation of a given reality that is presented as limiting possibilities." Such a definition was the basis guiding the following formative actions and activities.

Secondly, Pedagogical Coordinators produced a management plan, a tool collaboratively developed to organize the formative activities at school. To produce the management plan, the Pedagogical Coordinators had to define the school need, referred to in the excerpt as drama, and then project a joint object that would guide the formative activities. Such activities were organized in three stages: studying, educating, and monitoring. Excerpt 2 describes how the school organized to draw up their dramas.

\section{Excerpt 2:}

1. PCS. These are the only moments we meet, which are the pedagogical journey and the pedagogical meeting, and from there we could discuss which drama we had and that we needed to choose one.

2. R. Did you do this process with the students then?

3. PCS. We did it with the students and went to the community to find out their drama. 
4. R. Is it when you organized the wishing tree?

5. PCS. Yes, it was. We were thinking about what we wanted and what we wished for the school. We started with the dramas. Well, these are our dramas but in relation to these dramas think about what we wish. What we want to transform. "I wish my students had more opportunities to study." "I wish I had better working conditions." "I wish I had an interdisciplinary work with other people."

6. R. A team wishing tree.

The Pedagogical Coordinator started by pondering the activities they had in order to discuss the issues of their drama: the pedagogical journey and pedagogical meetings. The same procedure happened with the students, who listed their difficulties, mainly learning ones, and with the community. The pedagogical journeys and pedagogical meetings were creative encounters in which school members had the opportunity to design their joint object collaboratively (Miettinen, 2013) by means of togetherness, as suggested by van Oers and Hännikäinen (2001), through the wishing tree. The same happened with students and community members. Collaborative agency and togetherness were highlighted by the use of the pronouns "we" and "our" throughout Excerpt 2. Besides, by externalizing their wishes participants had the opportunity to externalize the problems they faced and project possibilities of transforming them.

Overall, the management plan was a key tool, the material that motivated pedagogical coordinators, teachers, and students to get deep into the community to draw up their drama and develop their joint object. However, instead of focusing on scientific texts during the studying moments, PCS decided to visit other stakeholders in the community to study community needs. During the monitoring moments, PCS participated in the stakeholders' meetings, such as the Health Care Unit and community association meetings. Thus, she could return to educating moments with teachers that happened during pedagogical meetings and educational journeys, two moments officially dedicated to teaching education.

The participation of Health Care Unit members, community association members, and teachers amplified the social scope of the educational management. Such a movement provided possibilities for more participatory organization and education at school and in the community.

\section{Teachers' and students' participation}

The teachers at the school directly involved in the project included one Portuguese teacher, two geography teachers, two physical education teachers and one arts teacher.

It is important to mention that those teachers were part of a specific project, the Specific Action Project (in Portuguese, PEA

- Projeto Especial de Ação), in which they were paid for eleven extra hours of work in their salary, two of them to take part in the Pedagogical Journey and the other nine to study and prepare for classes according to the project. However, this does not mean that other teachers could not take part in the project.

First, teachers discussed with PCS what their drama would be and drew them on the wishing tree as described on the previous section. Second, they created the project "My stream, my life," in which different curricular components and activities were planned and implemented to call community members' and authorities' attention to the flooding problem. After that, teachers incorporated the issue of flooding in their official annual planning by mentioning it in the general scope of the planning or in different tasks and activities. Finally, the different tasks and activities were implemented and evaluated throughout the process during pedagogical meetings and pedagogical journeys.

The Portuguese Language teacher worked on ways of writing an argumentative text in which students had to describe their problems and envision possibilities to solve them, and in addition, with the geography teachers developed a survey with which students would interview community members in order to gain an overview of the social organization of the community and the problems they faced by living in the favela, especially those related to the issue of flooding.

Geography teachers also organized a study about the course of the river, in which students needed to research the natural course of the river, other rivers that are affected by it, how its course changed over time, and how people started building their houses around it.

As the community does not have public space for leisure, the only space the community has is the school court, and although this is not officially allowed, the school, in agreement with the community, keeps the court gates open during the weekends for community members to use. Physical Education teachers discussed with the students what types of sports or leisure activities they would practice if they had such a space. As a result, they organized a race on the street close to the river and a human chess championship, after which the children could learn the techniques at school and play on the street close to the river, so they could envision how it would be to have such spaces. 
In line with the same idea of space use, the arts teacher organized a samba school using waste thrown out around the river to make instruments, costumes, and allegories. Students also wrote samba lyrics in which they had to describe the problems with the flooding and how they envisioned the clean river. The name of the samba school was "Get out of my way." Another task in the same line was for students to draw how they saw their community with flooding and how they envisioned it without flooding.

Although the ICT (Information and Communication Technology) and science teachers were not directly involved in the project, they also participated. The ICT teachers worked with the Portuguese teacher to support the students developing leaflets to invite community members to participate in the school and Health Care Unit meetings. Moreover, the ICT teacher also worked with the Portuguese Language and geography teachers to support students developing and tabulating the survey of the community members. The science teacher worked on the types of diseases that could be spread because of the flooding and the hygienic measures the students could take to avoid them.

The different activities organized by teachers and their students towards the joint object developed inside and outside the school in togetherness (van Oers \& Hännikäinen, 2001) characterized their collaborative agency (Miettinen, 2010, 2013). Such characteristics broke the boundaries of normative top-down educational management, in which teachers receive demands to be accomplished, to make the needs more visible and the object more tangible.

\section{Community participation}

According to Engeström and Ahonen (2005), communities need infrastructure to exist, but some of this infrastructure is created unexpectedly by dwellers facing certain realities in their contexts. Such infrastructure becomes so ordinary that it also becomes invisible to those who live in the community, and much more to those who do not live there, which is often the case of people who work at school.

First, the articulation between school and community began when the school team started participating in two different types of meetings: one organized by the community association and another organized by the district professionals. During this process, PCS and the school team found out their drama was mostly related to violence created outside school and brought into the classroom. For instance, students who were from different favelas and studied in the same classroom started fighting during classes because of issues they had outside school. Another example is that Mondays were considered very stressful days since students would have had quarrels or fights at parties over weekend that they wanted to resolve at school.

The violence in the environment created a very stressful situation at school, and violence manifested itself not only between students but within the school team. One idea was that violence was generated by the lack of leisure space in the community, so PCS sought help with the Health Care Unit psychologist who had started working with the school in order to resolve the issue of violence. PCS then reported that there were other issues in the Health Care Unit involving the same age group that was going to school.

PCS, the psychologist, Health Care Unit manager, nurses, and a social worker then discussed their dramas and found out that many of the students, both children and teenagers, who should have visited the Health Care Unit to get vaccinations did not do so, increasing the incidence of certain diseases in the community, so the school began calling parents' and students' attention to vaccination programs. On the other hand, the school had high rate of absences because of diseases spread by the garbage, for which there was no proper treatment, and the water contamination.

\section{Excerpt 3:}

31. PCS. So, I wondered. Why are students so unruly in the classroom? So, we began to realize that there is no space for leisure. So, we began to realize that every day our students miss class because they have headaches, the Health Care Unit mentioned everything has to do with the health. And we then thought about working on joint actions involving education, health, and community members, and not think that the school's drama belongs only to the school. The school's drama indeed belongs to school, but I have to share it with others. And then we found out that other people could help in our drama, and then we discovered our joint object, and that's when the river came out.

After discussing the school's and Health Care Unit's drama, they realized they would need strong support from the community members to draw a joint object and plan activities that would help them overcome their problems. Therefore, instead of each party-the school, Health Care Unit 
and community association-struggling individually to solve their individual issues, they started working in togetherness (van Oers and Hännikäinen, 2001), potentiating their efforts to overcome the flood issue. Such togetherness was realized in the discourse by references to the different stakeholders taking part in the process-the school, Health Care Unit and community association-the relationship between PCS and the others, and the pronoun "we."

The first meeting took place in the Health Care Unit in September 2011. There were around thirty people, including PCS, teachers, students, and community members, who happened for the most part to be students' parents or tutors, Health Care Unit manager, nurses, and a social worker. After that meeting they organized a meeting each month in a different place-the Health Care Unit, school, and different community associations. During those meetings, they discussed which were the main issues faced by the community, what they could solve together, what they would need politicians, city councilmen, or the deputy mayor to support, and how to reach them.

Such meetings can be characterized as creative encounters in which participants expand their expertise (Miettinen, 2010, 2013) and their power of togetherness (van Oers \& Hännikäinen, 2001) through a social and material organization to solve their problem. Instead of blindly accept the materiality of their contexts, participants engaged in a movement to envision new possibilities to transform their future in collaborative agency.

\section{Envisioning the future}

As a final product, the pedagogical coordinator produced a manifesto based on the meetings and community members' testimony. As the sequential trajectory of the activities previously organized, after making the community aware of their problem, school and community leaders collected signatures of different people so that they could deliver an official document requiring that a linear park be built on the stream. Through the movement established between school and community towards the solution of the flooding they participated in the 1st Prize in Human Rights in the city of São Paulo, winning third place. The mayor, the Secretary of Education, and the Secretary of Human Rights were present in the event.

After delivering more than 2000 signatures, one of the community leaders became a representative to the regional security council (in Portuguese, CONSEG), which provided closer access to politicians, thereby improving the possibilities of the community being heard by the authorities. This happened on the week I was immersed in the school and had the opportunity to join in their meeting, as every week the city councilmen's assembly opens its microphone to the public so that common citizens could speak for three minutes. They planned to attend the next assembly and use the three minutes to read the manifesto.

At the beginning of 2014, around March, the councilman that represented the South Region of São Paulo visited the school and started developing a project with the students and community to solve community issues, including the flooding. After that, the Secretariat of the Environment and Nature started cleaning up the river and developed a project for a linear park where the river is located. Due to the efforts made by the school, Health Care Unit, and community members, the school was recognized in the ceremonies recognizing the 25th anniversary of the Child and Adolescent Act in 2015 as a place that struggles to guarantee children's and teenagers' rights.

Therefore, more than producing the expertise to solve their problem, the school and its community planted the seeds for a different form of school organization than they were used to, an organization that provided them the chance to make education and educational management expand beyond the school walls, beyond the favela, and beyond their district.

\section{DISCUSSION}

The theoretical insights gained through this study involve the collaborative agentive movement throughout the case. Firstly, by considering the need to project a joint object to organize educational management, and secondly by developing the tools that enabled the transformation of educational management within and beyond the school walls. Such a movement reveals the importance of the materiality embedded in CHAT to the transformation of educational management settings.

Moreover, this study shows the possibility of educational management expansion from a hierarchical management organization in which the pedagogical coordinator would follow the rules proposed by the upper levels of the educational system to an expansive management in which the formative intervention triggers an intervention transforming the school and the local community.

Such expansion does not happen because of the need for a more altruistic view of the school as an organization. Unlike Marquis, Glynn, and Davis (2007), who analyzed several cases in which companies needed to develop social measures to make community members become potential clients, in the case of a school students have the right to attend school and teachers have the right to work there, so they need to improve the school and community conditions in order to improve their own working 
and learning conditions. In the cases discussed by Marquis et al. (2007), clients can decide whether or not to be a client, while in the case of a school, students must attend it.

Reconnecting the discussion to the topic of this special issue, sociomateriality permeates the discussion throughout this paper when considering how subjects collectively expressed and addressed their needs and developed tools to reach their object while facing the challenges presented by the school context, thereby expanding educational management.

\section{CONCLUSIONS}

In summary, the objective of this study was to analyze how improving educational management activities can lead to the transformation of a school and its surroundings.

First, there were the extensive efforts of the school pedagogical coordinator to bring her conception of educational management into reality at her school ever since the first meeting at the Regional Board of Education. However, this effort became stronger when the teachers started working collaboratively and together to reorganize their curricula, so that their joint object could be fulfilled in the school on a daily basis and not only as an extracurricular project.

Despite the challenges of working within an educational system that demands more focus on results of tests and assessments due to the context of social vulnerability, it was essential for the improvement of educational management. The collaborative agency developed by different stakeholders, such as the Health Care Unit members, community members, and school team, provided a chance to project a joint object. More than that, by means of this togetherness they could plan and implement activities that would provide for the envisioning of future possibilities. Such activities take into consideration an important number of artefacts that enrich the sociomateriality of the educational management organization, such as the wishing tree, samba school, and musical instruments made from the garbage thrown in the river, mainly concerning how their community could become a healthier place to live.

Therefore, we discussed how collaboratively agentive movement contributed to calling authorities' attention to the problems in the community and school, with the flooding taking the school to the community and the community to the school. Collaborative agency contributed to the expansion of educational management through activities organized beyond school walls.

\section{ACKNOWLEDGEMENTS}

I would like to thank CIMO and The Academy of Finland for the funding. Besides, I would like to express my gratitude to Professors Fernanda Liberali and Reijo Miettinen for their valuable insights during the research for and paper. I also would like to thank the Class of 2012 of the Doctoral Program of Developmental Work Research and Adult Education at University of Helsinki and the Language and Activity in Educational Contexts team at the Pontifical Catholic University of São Paulo, specially Marcia Pereira de Carvalho, Viviane Carrijo, Maria Cristina Meaney and Fernando Rezende da Cunha Junior for their comments at different moments of the paper writing. Finally, I would like to express my deepest gratitude to the reviewers and editors, whose comments and suggestions enabled the refinement and improvement of the paper.

\section{REFERENCES}

Bakhtin, M. (1952). The problem of speech genre. In Bakhtin, M. (Ed), Speech genres and other late essays. Austin, USA: University of Texas Press.

Brasil. (1988). Constituição da República Federativa do Brasil. Casa Civil, S. P. A. J. Brasília, DF: Governo Federal.

Brasil. (1996) Leis de diretrizes e bases da educação. Cultura, M. D. E. E. Brasil: Ministério da Educação e Cultura. 9394/96.

Bush, T. (2011). Theories of educational leadership and management ( $4^{\text {th }}$ ed.). London, UK: SAGE Publications.

Cunha, F. R. D., Jr., van Kruistum, C., van Oers, B., (2016). Teachers and Facebook: Using online groups to improve students' communication and engagement in education. Communication Teacher, 30(4), 228241. doi:10.1080/17404622.2016.1219039

Engeström, Y. (1991). Non scolae sed vitae discimus: Toward overcoming the encapsulation of school learning. Learning and Instruction, 1(3), 243-259.doi:10.1016/0959-4752(91)90006-T

Engeström, Y. (1994). Teachers as collaborative thinkers: Activity-theoretical study of an innovative teacher team. In I. Carlgren, G. Handal, \& S. Vaage (Eds.), Teachers' minds and actions: Research on teachers' thinking and practice (pp. 43-61). London, UK: Falmer Press.

Engeström, Y. (1995). Objects, contradictions and collaboration in medical cognition: An activity-theoretical perspective. Artificial Intelligence in Medicine, 7(5), 395-412.doi:10.1016/0933-3657(95)00012-U 
Engeström, Y. (2003). The horizontal dimension of expansive learning: Weaving a texture of cognitive trails in the terrain of health care in Helsinki. In F. Achtenhagen \& E. G. John (Eds.), Milestones of vocational and occupational education and training: The teaching-learning perspective (pp. 153-180). Bielefeld, Germany: Bertelsmann.

Engeström, Y. (2009a). The future of activity theory: A rough draft. In A. Sannino, H. Daniels, \& K. Guitierrez (Eds.), Learning and expanding with activity theory (pp. 303-328). New York, USA: Cambridge.

Engeström, Y. (2009b). Wildfire activities: New patterns of mobility and learning. Journal of Mobile and Blended Learning, 1(2), 1-18.

Engeström, Y. (2015). Learning by expanding: An activity-theoretical approach to developmental research (2nd ed.). Cambridge, USA: Cambridge University Press.

Engeström, Y., \& Ahonen, H. (2005). On the materiality of social capital: An activity-theoretical exploration. Helsinki, Finland: Helsinki University.

Engeström, Y. Engeström, R., \& Suntio, A. (2002). Can a school community learn to master its own future? An activity-theoretical study of expansive learning among middle school teachers. In G. Wells \& G. Claxton (Eds.), Learning for life in the 21st century: Sociocultural perspectives on the future of education. Oxford, UK: Blackwell Publishers.

Engeström, Y., \& Sannino, A. (2010). Studies on expansive learning: Foundations, findings and future challenges. Educational Research Review, 5(1), 1-24. doi:10.1016/j.edurev.2009.12.002

Engeström, Y., Sannino, A., \& Virkkunen, J. (2014). On the methodological demands of formative interventions. Mind, Culture, and Activity, 21(2), 118-128. doi:10.1080/10749039.2014.891868

Fenwick, T. (2010). Re-thinking the "thing": Sociomaterial approaches to understanding and researching learning in work. Journal of Workplace Learning, 22(1-2), 104-116. doi:10.1108/13665621011012898

Fenwick, T., Edwards, R., \& Sawchuk, P. (2011). Emerging approaches to educational research: Tracing the socio-material. London, UK: Routledge.

Freire, P. (1970). Pedagogy of the oppressed. New York, USA: Herder and Herder.

Freire, P. (2014). Pedagogia da Autonomia. 49ª . Rio de Janeiro, RJ: Paz \& Terra.

Fuga, V. P. (2009). O movimento do significado de grupos de apoio na cadeia criativa de atividades no programa Ação Cidadã. (Unpublished doctoral dissertation). Pontifícia Universidade Católica de São Paulo, São Paulo, SP.

Hoy, W., \& Miskel, C. (2013). Educational administration: Theory, research, and practice ( $9^{\text {th }}$ ed.). New York, USA: McGraw-Hill College.

Instituto Nacional de Pesquisas Espaciais. (2010). Mudanças climáticas. São Paulo: Instituto Nacional de Pesquisa Espacial. Retrieved from www.inpe.br/noticias/noticia. php?Cod_Noticia=2215.

Kumpulainen, K., Krokfors, L., Lipponen, L., Tissari, V., Hilppö, J., \& Rajala, A. (2010). Learning Bridges Toward Participatory Learning Environments. Helsinki, Finland: Helsinki University Press.

Lemos, M. F. (2014) Collective concept formation of educational management. In: H. Knutgard, B. Krants, et al (Ed.). A Nordic perspective on the cultural and activity approach in theory and practice. Kristianstad: Kristianstad University Press, pp. 47-54.
Lemos, M. F. (2015). Collaborative agency in educational management: Constructing a joint object for school and community transformation. 9th International Conference on Researching Work \& Learning. Singapore: Government of Singapore.

Lemos, M. F. \& Engeström, Y. (Submitted manuscript). Collective concept formation in educational management: An intervention study in São Paulo, Brazil.

Leontiev, A. N. (1978). Activity, consciousness and personality. Englewood Cliffs, NJ: Prentice Hall. Retrieved from www.marxists.org_archive_leontev_works_activity-consciousness.

Liberali, F. C. (2012a). Gestão escolar em cadeias criativas. Brasília, DF: CNPq.

Liberali, F. C. (2012b). Gestão escolar na perspectiva da teoria da atividade sócio-histórico-cultural. In F. Liberali, E. Mateus, \& M. C. Damianovic (Eds.), A teoria da atividade sócio-histórico-cultural e a escola: Recriando realidades sociais. Campinas: Pontes.

Liberali, F. C. (2013). Argumentação em contexto escolar. Campinas, SP: Pontes Editores.

Liberali, F., Borelli, S., \& Lima, M. E. (2015). Gestão escolar em cadeias criativas: Um processo para transformações escolares. In K. A. Silva, M. Maristella-de-Andrade, \& C. Pereira (Eds.), A formação de professores de línguas: políticas, projetos e parcerias (vol. 1) (pp. 93-141) Campinas, SP: Pontes Editora.

Lourenço Filho, M. (1968). Organização e administração escolar (3rd ed.). São Paulo, SP: Melhoramentos.

Lück, H. (2009). Dimensões da gestão escolar e suas competências. Curitiba, PR: Positivo.

Magalhães, M. C. C. (2016). Intervention research in a public elementary school: A critical-collaborative teacher education project on reading and writing. Outlines - Critical Practice Studies, 17(1), 39-61.

Marquis, C., Glynn, M. A., \& Davis, G. F. (2007). Community isomorphism and corporate social action. Academy of Management Review, 32(3), 925-945. doi:10.5465/AMR.2007.25275683

Miettinen, R. (2010). Creative encounters and the emergence of object-oriented collaborative agency. Lisbon, Portugal: European Group of Organizational Studies.

Miettinen, R. (2013). Creative encounters and collaborative agency in science, technology and innovation. In K. Thomas \& J. Chan (Eds.), Handbook of research on creativity (pp. 435-449). Cheltenham, UK: Edward Elgar Publishing.

Rantavuori, J., Engeström, Y., \& Lipponen, L. T. (2016). Learning actions, objects and types of interaction: A methodological analysis of expansive learning among pre-service teachers. Frontline Learning Research, 4(3), 1-27.

Sahlberg, P. (2011). Finnish lessons: What can the world know from educational change in Finland? New York, USA: Teachers College Press.

Sannino, A., Engeström, Y., \& Lemos, M. (2016). Formative interventions for expansive learning and transFormative agency. Journal of the Learning Sciences. doi:10.1080/10508406.2016.1204547

Souza, Â. R. (2006). O perfil da gestão escolar no Brasil. (Unpublished doctoral dissertation). Educação: História, Política e Sociedade, Pontifícia Universidade Católica de São Paulo, São Paulo, Brazil. 
Teixeira, A. (1961). Que é administração escolar? Revista Brasileira de Estudos Pedagógicos, 36(84), 84-89.

UN-Habitat. (2003). The challenge of slums. London, UK: Earthscan Publications Ltd. van Oers, B., \& Hännikäinen, M. (2001). Some thoughts about togetherness: An introduction. Reflexions sur e togetherness $f$ algunos pensamientos sobre el sentimiento de unión. International Journal of Early Years Education, 9(2), 101-108.doi:10.1080/0966976012005346 6 